\title{
Successful generation of anti-ToCV and TYLCV transgenic tomato plants by RNAi
}

\author{
F.-M. JIN*, J. SONG, J. XUE, H.B. SUN, Y. ZHNAG, S. WANG, and Y.-H. WANG \\ Tianjin Research Center of Agricultural Biotechnology, Tianjin, 300192, P.R.China
}

\begin{abstract}
Tomato is an economically important vegetable. Tomato chlorosis virus (ToCV) and Tomato yellow leaf curl virus (TYLCV) are two major viruses that cause serious losses to tomato production. The effective method to control these two viruses is to breed antiviral species by genetic engineering techniques. In order to obtain the RNA interference (RNAi) expression vector of tomato, the coat protein $(C P)$ genes of ToCV and TYLCV were selected in this study. The tandem sequences of the two $C P$ genes were obtained using the recombinant PCR technique. Using Gateway cloning technology, the RNAi expression vector pRNAi-ToCV-TY including the two $C P$ genes was constructed by attB $\times$ attP and attL $\times$ attR recombination reactions. Polymerase chain reaction and sequencing analysis confirmed that the vector was obtained successfully and contained the ToCV and TYLCV CP genes. The RNAi expression vector pRNAi-ToCV-TY was transformed into Agrobacterium strain GV3101. The RNAi vector was then used to transform tomato. The objective fragments were successfully transformed into a tomato by PCR identification. At the fourth-leaf stage, the positive transgenic plants were challenged with ToCV and TYLCV. Out of 15 transgenic plants, $33 \%$ showed early symptoms within 4 weeks post-infection (WPI); $20 \%$ showed delayed symptoms (5 - 7 WPI); and the remaining $47 \%$ were symptomless even after 9 WPI. The untransformed control plants $(90 \%)$ showed severe symptoms within 2 - 4 WPI, whereas $10 \%$ delayed symptoms.
\end{abstract}

Additional key words: Agrobacterium-mediated transformation, coat protein, Solanum lycopersicum.

\section{Introduction}

The tomato (Lycopersicon esculentum L. or Solanum lycopersicum L.) is an economically important vegetable. Tomato chlorosis virus (ToCV) and tomato yellow leaf curl virus (TYLCV) are the two major viruses that cause serious losses to tomato production (Jin et al. 2011, 2016, Pasev et al. 2012, Chinnaraja et al. 2016). The number of these two viruses has been increasing at a global scale and has become an important limiting factor for tomato production in many parts of the world.

The ToCV, belonging to the genus Crinivirus (Closteroviridae), is a whitefly-transmitted virus with bipartite RNA genomes RNA1 and RNA2. The RNA1 comprises 8594 nucleotides with four open reading frames (ORFs). The RNA2 has 8242 nucleotides and encodes nine ORFs including a heat shock protein 70 and the coat protein (CP) (Wisler et al. 1998). Infected tomato plants exhibit yellow thick leaves and dark veins, which greatly reduce the quality and yield of tomato.

The TYLCV belongs to the genus Begomovirus (Geminiviridae) and is a DNA virus that can be also transmitted by the whitefly. It consists of a single circular DNA molecule comprising 2781 nucleotides and has six ORFs. The CP is encoded by the viral strand (Jin et al. 2011). The infected plants have yellow veins, curved and shriveled leaves, and a dwarf phenotype. The two viruses have recently often been observed to co-infect tomato, aggravating the disease and causing severe yield and quality declines (Zhao et al. 2014, Wu et al. 2016, Liu et al. 2018, Song et al. 2019). It is thus necessary to breed tomato cultivars that are resistant to ToCV and TYLCV.

Submitted 9 January 2020, last revision 19 April 2020, accepted 11 May 2020.

Abbreviations: 6-BA - 6-benzylaminopurine; BP - attB $\times$ attP; CGMMV - Cucumber green mottle mosaic virus; CP - coat protein; dNTP - deoxynucleotide triphosphate; IAA - indole-3-acetic acid; kan - kanamycin; LB - left border; LR - attL $\times$ attR; MS - Murashige and Skoog; ORF - open reading frame; dsRNA - double-stranded RNA; RB - right border; RT-PCR - reverse transcription PCR; TLCV - Tomato leaf curl virus; TMV - Tobacco mosaic virus; ToCV - Tomato chlorosis virus; TYLCV - Tomato yellow leaf curl virus; RNAi - RNA interference; WPI - weeks post-infection.

Acknowledgments: This study was supported by the major projects of Seed Industry Science and Technology in Tianjin (grant No. 16ZXZYNC00070), the project of Science and Technology Commissioner in Tianjin Enterprise (grant No. 19JCTPJC58400), the project Agricultural Science and Technology Demonstration in Tianjin (grant No. 201901020), and the director fund project of Tianjin Agricultural Biotechnology Research Center (grant No. 2019003). We also thank LetPub (www.letpub.com) for its linguistic assistance during the preparation of this manuscript.

* Corresponding author; fax: (+86) 022-27950828, e-mail: jinfm414@163.com 
The introduction of resistance genes found in wild tomato species into tomato cultivars has been employed in breeding for improving resistance to TYLCV (Pilowsky et al. 1990, Zakay et al. 1990). However, this method is ineffective in ToCV. To date, there have been no reports oncultivars resistant to ToCV (Liu et al. 2018). It is therefore urgent to obtain tomato genotype resistant to ToCV.

In recent years, RNA interference (RNAi) technology, which can silence foreign viruses, has become the most effective method for improving plant resistance. The double-stranded RNA (dsRNA) model proposed by Waterhouse et al. (1998) as a form of RNAi technology is currently accepted as a gene silencing mechanism. In the dsRNA-mediated resistance to viruses, an inverse repeat sequence derived from the virus is delivered to the plant. The inverse repeat sequence can be transcribed to dsRNA in plants, which induces gene silencing when the foreign virus infects the plant. The transgenic plant then becomes resistant to viruses (Baulcombe 1999, Stoutjesdijk et al. 2002). The dsRNA technology has been gradually applied in the prevention and control of plant viruses. For example, the polyprotein gene inverse repeat of the barley Yellow dwarf virus-PAV (BYDV-PAV) was transferred to barley, which enabled 9 out of 25 plants to be immune to the disease (Wang et al. 2000). The inverted repeat structure of the Tomato mosaic virus movement protein gene (ToMV-MP) was transformed into tobacco, and 23 out of 47 plants became immune to ToMV (Niu et al. 2003). The $C P$ gene inverted repeat of papaya Ringspot virus (PRSV) was transferred into tobacco and Arabidopsis by an Agrobacterium-mediated method, resulting in resistant plants (Zhang and Jiang 2011). However, the transformation of tomato with the $C P$ gene of TYLCV and the $C P$ gene of ToCV has never been attempted to improve the resistance of tomato to TYLCV and ToCV.

The construction method of the homologous recombinant RNAi expression vector represented by Gateway is widely used for its high efficiency and rapidity (Oey et al. 2014, Salim et al. 2016, Marino et al. 2017). There have been many reports on the use of Gateway technology to construct anti-plant virus expression vectors (Tian and Niu 2013, Xu et al. 2011). Gateway technology is a DNA recombinant cloning technology that was developed based on the homologous recombination system of the phage. It is an improvement to the traditional plasmid construction model, and the target gene can be efficiently and rapidly constructed into an expression vector only by the attB $\times$ attP $(\mathrm{BP})$ and attL $\times$ attR $(\mathrm{LR})$ reactions, and the cloning step is greatly reduced. It guarantees an accurate reading framework and gene mapping (Hartley et al. 2000). Reverse repeats can be obtained directly using this technique, avoiding repeated digestion and ligation.

The CP is the conservative protein in TYLCV and ToCV. The homology of the TYLCV CP in Tianjin isolate (GU563330) compared to that of the most isolates in China and Korea, Japan, Jordan, Israel, America, and Mexico is over $99 \%$ (Jin et al. 2016). The homology of the ToCV CP in Tianjin isolate (KP246844) to that of the most isolates in China and Korea, Japan, and America is over $99 \%$ (Jin et al. 2011). We thus aimed to construct a binary dsRNA expression vector of the $C P$ genes of TYLCV and ToCV using Gateway technology, further transforming tomato to develop an antiviral material in order to regenerate transgenic plants resistant to TYLCV and ToCV.

\section{Materials and methods}

Nucleic acid extraction: Tomato leaves with typical TYLCV and ToCV symptoms were collected in Xiqing District, Tianjin. Total plant DNA was isolated from leaves of TYLCV-infected plants by cetyltrimethyl ammonium bromide (CTAB), as described by Wang and Fang (2002). Total RNA was extracted from the leaves of the ToCVinfected plants using an RNA extraction kit (Takara, Dalian, China).

Amplification of partial ToCV and TYLCV CP gene fragments: The primers TY-F/R (Table 1 Suppl.) were designed according to the sequence of the TYLCV Tianjin isolate (GU563330). The partial TYLCV CP fragment (1 to 405 in the $C P$ gene) was amplified by the primers TY-F/R. In order to connect with $T o C V C P$ fragment, the forward primer TY-F has an overlapping sequence with ToCV-R. The total PCR volume was $25 \mathrm{~mm}^{3}$, including $2.5 \mathrm{~mm}^{3}$ of $10 \times$ buffer (containing $\mathrm{Mg}^{2+}$ ), $0.5 \mathrm{~mm}^{3}$ deoxynucleotide triphosphate (dNTP) mixture $(2.5 \mathrm{mM}), 2.5 \mathrm{~mm}^{3}$ of forward primer TY-F $(10 \mu \mathrm{M}), 2.5 \mathrm{~mm}^{3}$ of reverse primer TY-R $(10 \mu \mathrm{M}), 0.5-2 \mathrm{~mm}^{3}$ of DNA, and $0.5 \mathrm{~mm}^{3}$ of DNA polymerase $\left(5 \mathrm{U} \mathrm{mm}^{-3}\right)$ (Takara), and the remainder was supplemented with water. The partial ToCV CP fragment (1 - 432 in the $C P$ gene; 4332 - 4763 in RNA2) was obtained by reverse transcription PCR (RT-PCR). The primer ToCV-F/R (Table 1 Suppl.) was designed according to the sequence of the ToCV Tianjin isolate (KP246844). The first strand of cDNA was synthesized by $M-M L V$ reverse transcriptase (Takara) with Oligo dT primer. The total PCR volume was $10 \mathrm{~mm}^{3}$, including $1 \mathrm{~mm}^{3}$ of RNA, $1 \mathrm{~mm}^{3}$ of oligo dT primers, and $0.5 \mathrm{~mm}^{3}$ of dNTP, and the remainder was supplemented with water. After denaturing at $70{ }^{\circ} \mathrm{C}$ for $10 \mathrm{~min}$ and incubating on ice for $2 \mathrm{~min}$, the following reagents were added to the total volume: $5 \mathrm{~mm}^{3}$ $\times M-M L V$ buffer, $1 \mathrm{~mm}^{3}$ of $M-M L V$, and $0.5 \mathrm{~mm}^{3}$ of RNAase inhibitor. Then, it was incubated at $37^{\circ} \mathrm{C}$ for $1 \mathrm{~h}$. The total PCR volume was $25 \mathrm{~mm}^{3}$, including $2.5 \mathrm{~mm}^{3}$ of $10 \times$ buffer (containing $\mathrm{Mg}^{2+}$ ), $0.5 \mathrm{~mm}^{3}$ of dNTP mixture $(2.5 \mathrm{mM}), 2.5 \mathrm{~mm}^{3}$ of forward primer ToCV-F $(10 \mu \mathrm{M})$, $2.5 \mathrm{~mm}^{3}$ of reverse primer ToCV-R $(10 \mu \mathrm{M}), 0.5-2 \mathrm{~mm}^{3}$ of cDNA, and $0.5 \mathrm{~mm}^{3}$ of DNA polymerase $\left(5 \mathrm{U} \mathrm{mm}^{-3}\right)$ (Takara), and the remainder was supplemented with water.

The PCR program consisted of initial denaturation ( $94{ }^{\circ} \mathrm{C}$ for $2 \mathrm{~min}$ ) followed by 35 cycles of denaturation $\left(94^{\circ} \mathrm{C}\right.$ for $\left.30 \mathrm{~s}\right)$, annealing $\left(53^{\circ} \mathrm{C}\right.$ for $\left.30 \mathrm{~s}\right)$, and extension $\left(72{ }^{\circ} \mathrm{C}\right.$ for $1.5 \mathrm{~min}$ ), with final extension at $72{ }^{\circ} \mathrm{C}$ for $10 \mathrm{~min}$. After amplification, the PCR products were recovered and sequenced.

Tandem gene acquisition of the partial ToCV $C P$ and TYLCV CP: The obtained PCR products of the partial 
TYLCV CP and ToCV CP as the template were mixed, and PCR was carried out using primers ToCV-F and TY-R (Table 1 Suppl.) to obtain a tandem gene fragment of partial TYLCV CP and ToCV CP. The total volume of the PCR mixture was $50 \mathrm{~mm}^{3}$, with $25 \mathrm{~mm}^{3}$ of $2 \times$ SG PCR MasterMix (SinoGene Scientific Co., Beijing, China), $1 \mathrm{~mm}^{3}$ of $\left(100 \mathrm{ng} \mathrm{mm}^{-3}\right)$ of each template, $2.5 \mathrm{~mm}^{3}$ of forward primer $(10 \mu \mathrm{M})$, and $2.5 \mathrm{~mm}^{3}$ of reverse primer $(10 \mu \mathrm{M})$, and the remainder was supplemented with water. The PCR procedure included denaturation at $94{ }^{\circ} \mathrm{C}$ for $2 \mathrm{~min} ; 94^{\circ} \mathrm{C}$ for $30 \mathrm{~s}, 54{ }^{\circ} \mathrm{C}$ for $30 \mathrm{~s}, 72^{\circ} \mathrm{C}$ for $1.5 \mathrm{~min}$, 35 cycles; and $72{ }^{\circ} \mathrm{C}$ for $10 \mathrm{~min}$. The PCR product was electrophoresed on $1 \%(\mathrm{~m} / \mathrm{v})$ agarose gel, and the tandem gene fragment was recovered using a PCR purification kit (Tiangen Biochemical Technology Co., Beijing, China) according to the manufacturer's protocol. The tandem gene fragment was named ToCV-TY. ToCV-TY was then ligated into the pMD18-T vector (Takara) and named P-ToCV-TY.

Expression vector construction: Using the plasmid P-ToCV-TY as the template, PCR was performed with primers attB-ToCV-F and attB-TY-R (Table 1 Suppl.). The attB adapters were then added forward and reverse of the tandem gene. According to the instructions of the Gateway LR clonase enzyme mix kit (Invitrogen, Carlsbad, CA, USA), the PCR product with the attB adapters reacted with the entry vector pDONRTM 221 (Invitrogen) by BP reaction. The reaction product was transformed into DH5 $\alpha$ by heat shock method and the transformed cells were uniformly spread on Luria-Bertani (LB) solid medium containing $50 \mu \mathrm{g} \mathrm{cm}^{-3}$ kanamycin (kan). After incubating at $37{ }^{\circ} \mathrm{C}$ for $16 \mathrm{~h}$, PCR was carried out using the primers $\mathrm{M} 13 \mathrm{~F} / \mathrm{R}$. The positive clones were selected, and then sequenced. The correct clones were named pENTR-ToCVTY.

Plasmids were extracted from positive clones to obtain entry vector pENTR-ToCV-TY. The vector was reacted with the expression vector pK7GWIWG2(I) (SinoGene Scientific) by LR reaction. The reaction product was transformed into $\mathrm{DH} 5 \alpha$, and the transformed cells were detected by the primers p35SP and TY-R. The colonies with the expected band were further sequenced with P35SP and T35SP to verify the insert direction. The positive clone in the correct direction was selected and named pRNAiToCV-TY (Fig. 1).

The expression vector (pRNAi-ToCV-TY) was transformed into Agrobacterium GV3101 (Tiangen) by freeze-thawing. Selected colonies were screened by PCR using the specific primers ToCV-F and TY-R and p35SP and TY-R. A positive colony containing the pRNAi-ToCVTY construct (Fig. 1) was used for tomato transformation.

Genetic transformation of tomato and identification of transgenic plants: The tomato (Solanum lycopersicum L.) susceptible inbred line J501 was preserved at the Tianjin Research Center of Agricultural Biotechnology. Healthy tomato seeds of J501 were surface-sterilized in $10 \%(\mathrm{~m} / \mathrm{v})$ commercial bleach ( $15 \%$ hypochlorite) for $15 \mathrm{~min}$, washed in sterile water, and set to germinate on half-strength
Murashige and Skoog (MS) medium. Cotyledon explants of two-week-old seedlings were used, and the transformation was performed as described previously (McCormick et al. 1986, 1991). The cotyledons of the explants were soaked for $5 \mathrm{~min}$ with Agrobacterium liquid medium (absorbance at $60 \mathrm{~nm}$ of 0.5 ). The blot-dried explants were replaced on the same plate and incubated in the dark at $25{ }^{\circ} \mathrm{C}$ for $3 \mathrm{~d}$. After co-cultivation, the cotyledonary leaf discs were transferred onto selection medium [MS containing $2.0 \mathrm{mg} \mathrm{dm}^{-3}$ of 6-benzylaminopurine (6-BA) and $0.2 \mathrm{mg} \mathrm{dm}^{-3}$ of indole-3-acetic acid (IAA), supplemented with $100 \mathrm{mg} \mathrm{dm}^{-3}$ of kan, and $500 \mathrm{mg} \mathrm{dm}^{-3}$ of cefotaxime]. The explants were removed, and the residual bacterial solution was blotted on sterile filter paper and transferred to MS medium containing IAA $\left(0.2 \mathrm{mg} \mathrm{dm}^{-3}\right)$ and 6-BA $\left(2.0 \mathrm{mg} \mathrm{dm}^{-3}\right)$ for $3 \mathrm{~d}$. Following this, it was transferred to a screening medium containing cephalosporin $\left(500 \mathrm{mg} \mathrm{dm}^{-3}\right)$ and $\mathrm{kan}\left(50 \mathrm{mg} \mathrm{dm}^{-3}\right)$, and cultured three weeks. The plates were kept at $25^{\circ} \mathrm{C}$, a $16-\mathrm{h}$ photoperiod, and an irradiance of $45 \mu \mathrm{mol} \mathrm{m} \mathrm{m}^{-2} \mathrm{~s}^{-1}$ in the culture room. Sub-culturing was performed at 2- to 3-week intervals, and explants showing shoot regeneration were subsequently transferred to the same medium but with a different phytohormone $\left(1.0 \mathrm{mg} \mathrm{dm}^{-3}\right.$ of IBA) for shoot development. The roots were developed and transplanted into the soil. The established plants were designated as T0generation plants.

To confirm the presence of the ToCV-TY gene in the T0 generation plants, total DNA was isolated from all transformed and untransformed (negative control) plant samples. The DNA was subjected to PCR using the primers TY-R and P35SP. The total PCR volume was $25 \mathrm{~mm}^{3}$, including $2.5 \mathrm{~mm}^{3}$ of $10 \times$ buffer (containing $\mathrm{Mg}^{2+}$ ), $0.5 \mathrm{~mm}^{3}$ of dNTP $(2.5 \mathrm{mM})$ mixture, $2.5 \mathrm{~mm}^{3}$ of forward primer $(10 \mu \mathrm{M}), 2.5 \mathrm{~mm}^{3}$ of reverse primer $(10 \mu \mathrm{M})$, $0.5-2 \mathrm{~mm}^{3}$ of DNA, and $0.5 \mathrm{~mm}^{3}$ of DNA polymerase $\left(5 \mathrm{U} \mathrm{mm}^{-3}\right)$, and the rest was supplemented with water. The PCR program consisted of initial denaturation $\left(94^{\circ} \mathrm{C}\right.$ for $2 \mathrm{~min}$ ) followed by 35 cycles of denaturation $\left(94{ }^{\circ} \mathrm{C}\right.$ for $30 \mathrm{~s})$, annealing $\left(53^{\circ} \mathrm{C}\right.$ for $\left.30 \mathrm{~s}\right)$, and extension $\left(72{ }^{\circ} \mathrm{C}\right.$ for $1.5 \mathrm{~min}$ ), with final extension at $72^{\circ} \mathrm{C}$ for $10 \mathrm{~min}$.

Identification of resistance: The group of whiteflies (Bemisia tabaci) carrying TYLCV and ToCV were maintained on tomato seedlings in the Tianjin Agricultural Biotechnology Research Center. The positive transgenic plants were planted into an insect-proof greenhouse. At the fourth-leaf stage, they were challenged with ToCV and TYLCV using 10 - 20 viruliferous whiteflies and maintained in an insect-proof glasshouse to observe the development of disease symptoms for nine weeks postinoculation (WPI) during the winter season (October 2018 to December 2018). A set of untransformed control plants was also challenged with viruliferous whiteflies. The viruses of challenged transgenic and control plants were detected at 2 WPI and 9 WPI by PCR and RT-PCR, respectively. The DNA was isolated to detect TYLCV CP gene (144 - 716 bp) by PCR using primer shanghaiF/R (Table 1 Suppl.), and the RNA was isolated to detect $T o C V$ $C P$ gene (4 $301-5147$ bp in RNA2) by RT-PCR with 
primer ToCVCP-F/R (Table 1 Suppl.).

\section{Results}

The RT-PCR and PCR were performed using the total RNA and total DNA of plants infected with the ToCV and TYLCV viruses, respectively. Two fragments of 432 and 405 bp were obtained (Fig $2 A, B$ ). The sequencing results of TYLCV and ToCV showed that the homology in the Tianjin isolates (TYLCV was GU563330; ToCV was KP246844) was $100 \%$.

Overlapping PCR was conducted to gain ToCV and TYLCV interference segments using ToCV-F and TY-R as the primers, and the mixture of the ToCV CP and TYLCV CP PCR products as the template. The length of the interference segment was 837 bp (Fig. 2C). The PCR product was cloned into the pMD-18T vector and named P-ToCV-TY.

The entry vector pENTR-ToCV-TY was constructed by $\mathrm{BP}$ reaction with the ToCV-TY tandem fragment and pDONR221 vector, and the positive recombinant clone was confirmed by PCR using primers M13F/R. A fragment of $1100 \mathrm{bp}$ was amplified, which was significantly larger than the insert fragment (837 bp), indicating that the tandem gene fragment ToCV-TY was ligated into the vector (Fig. 2D). The entry vector was obtained, which was named pENTR-TOCV-TY.

The obtained entry vector was subjected to LR reaction with the expression vector pK7GWIWG2(I) to obtain an expression vector, which was transformed into DH5a and named pRNAi-ToCV-TY. Colony PCR was performed using the primers ToCV-F and TY-R, and the $837 \mathrm{bp}$ band was amplified (Fig. 2E), which was consistent with the size of the target fragment. The forward and reverse sequencing were performed using P35SP and T35SP, and the results showed that the direction and sequencing were correct. This verified that pRNAi-ToCV-TY was successfully transferred into DH5a.

The plasmid was extracted from DH5a and transformed into Agrobacterium strain GV3101. The target bands were amplified with primers ToCV-F and TY-R and P35SP and TY-R. The ToCV-F and TY-R primers amplified an $837 \mathrm{bp}$ band (Fig. $2 F$ ), which was consistent with the size of the target fragment. The PCR product of the P35SP and TY-R primers was approximately 1100 significantly longer than the insert fragment (Fig. $2 G$ ). This indicated that the expression vector had been successfully transferred into
Table 1. The degree of resistance observed after virus challenge in $\mathrm{T} 0$ generation transgenic plants

\begin{tabular}{lllll}
\hline & Total & Resistant & Tolerant & Susceptible \\
\hline Transgenic plants & 15 & $7(47 \%)$ & $3(20 \%)$ & $5(33 \%)$ \\
Untransformed & 10 & 0 & $1(10 \%)$ & $9(90 \%)$ \\
control plants & & & & \\
\hline
\end{tabular}

\section{GV3101.}

A total of 30 regenerated plants (Fig. $4 A$ ) were obtained by Agrobacterium-mediated transformation of tomato J501. Control and regenerated plant genomic DNA were extracted, and PCR was performed using the p35SP and TY-R primers. The results showed that a band of about $1100 \mathrm{bp}$ was amplified in 15 of the plants (Fig. $3 \mathrm{~A}$ ), while the control plants had no amplified bands, indicating that the target gene had been integrated into the tomato genome.

In this study, 15 positive $\mathrm{T} 0$ transgenic tomato plants were challenged with ToCV and TYLCV using viruliferous whiteflies (Bemisia tabaci), and the results showed that the resistance of plants to ToCV and TYLCV was significantly improved compared to the untransformed control plants (Table 1).

Untransformed control plants and transgenic plants showed no symptoms at $3 \mathrm{WPI}$, and no bands were amplified by PCR. At 4 WPI, the T0-generation transgenic plants showed variable degrees of resistance/tolerance/ susceptibility against TYLCV and ToCV compared to the untransformed control plants (Table 1). Nine of the untransformed control plants grew slowly, the old leaves turned yellow, and the new leaves were wrinkled and yellowed. Five transgenic plants $(4,9,10,11$, and 13) also showed the same symptoms. There were three transgenic plants $(6,7$, and 15) and one untransformed control plant that also showed obvious symptoms at $5-7$ WPI. The other seven transgenic plants $(1,2,3,5,8,12$, and 14) showed no symptoms until 9 WPI (Figs $4 B, C$ ).

Out of 15 transgenic plants, 5 (33\%) showed early symptoms within 4 WPI, $3(20 \%)$ showed delayed symptoms (5 - $7 \mathrm{WPI})$, and the remaining 7 (47\%) were symptomless even after 9 WPI. Nine $(90 \%)$ of the untransformed control plants showed severe symptoms within 4 WPI, while one (10\%) showed delayed symptoms.

The transgenic plants and untransformed control plants were further tested by PCR and RT-PCR, respectively. The specific primer shanghaiF/R for detecting the TYLCV CP gene and a specific primer ToCV CP-F/R for detecting

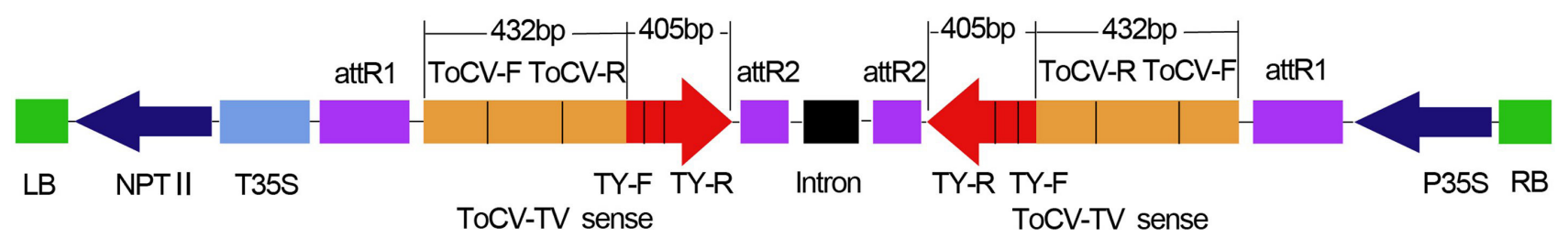

Fig. 1. The scheme of the recombinant expression vector pRNAi-ToCV-TY. The interference segment was cloned in a pK7GWIWG2(I) vector under the control of the cauliflower mosaic virus (CaMV) 35S promoter. The interference segment consisted of two ToCV-TY sequences and an intron. Two ToCV-TY sequences were connected in the antisense orientation, and there was an intron between them. The vector features kanamycin resistance due to the neomycin phosphotransferase II (NPTII) gene. 
the ToCV CP gene were used. The results showed that the target bands of about $573 \mathrm{bp}$ (TYLCV) and $847 \mathrm{bp}$ (ToCV) could be amplified in all plants, which were susceptible
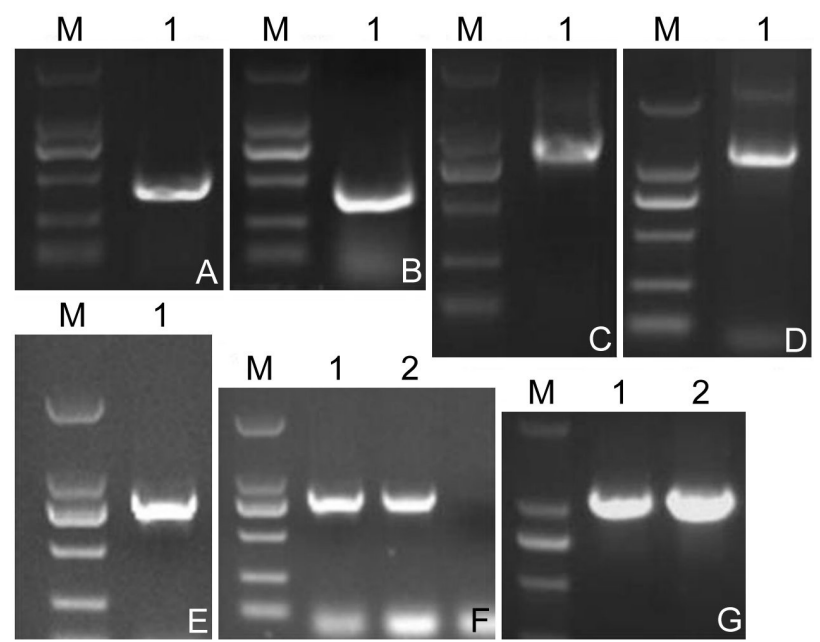

Fig. 2. Identification of gene fragments, an entry vector, and clones by PCR. $A-T o C V C P$ fragment (1), DL2000 (M); B - TYLCV CP fragment (1), $D L 2000$ (M); $C-T o C V-T Y$ gene fragment obtained using primers $T o C V-F$ and $T Y-R$ (1), DL2000 (M); D - entry vector obtained using primers $M 13 F / M 13 R$ (1), DL2000 (M); $E$ - clones of $p R N A i-T o C V-T Y$ transformed into DH5 $\alpha$ obtained using primers $T o C V-F$ and $T Y-R(1), D L 5000(\mathrm{M}) ; F, G$ - clones of pRNAi-ToCV-TY transformed into Agrobacterium strain GV3101 obtained using primers $T o C V-F$ and $T Y-R(F, 1,2)$ and $P 35 S P$ and $T Y-R(G, 1,2), D L 2000(\mathrm{M})$.
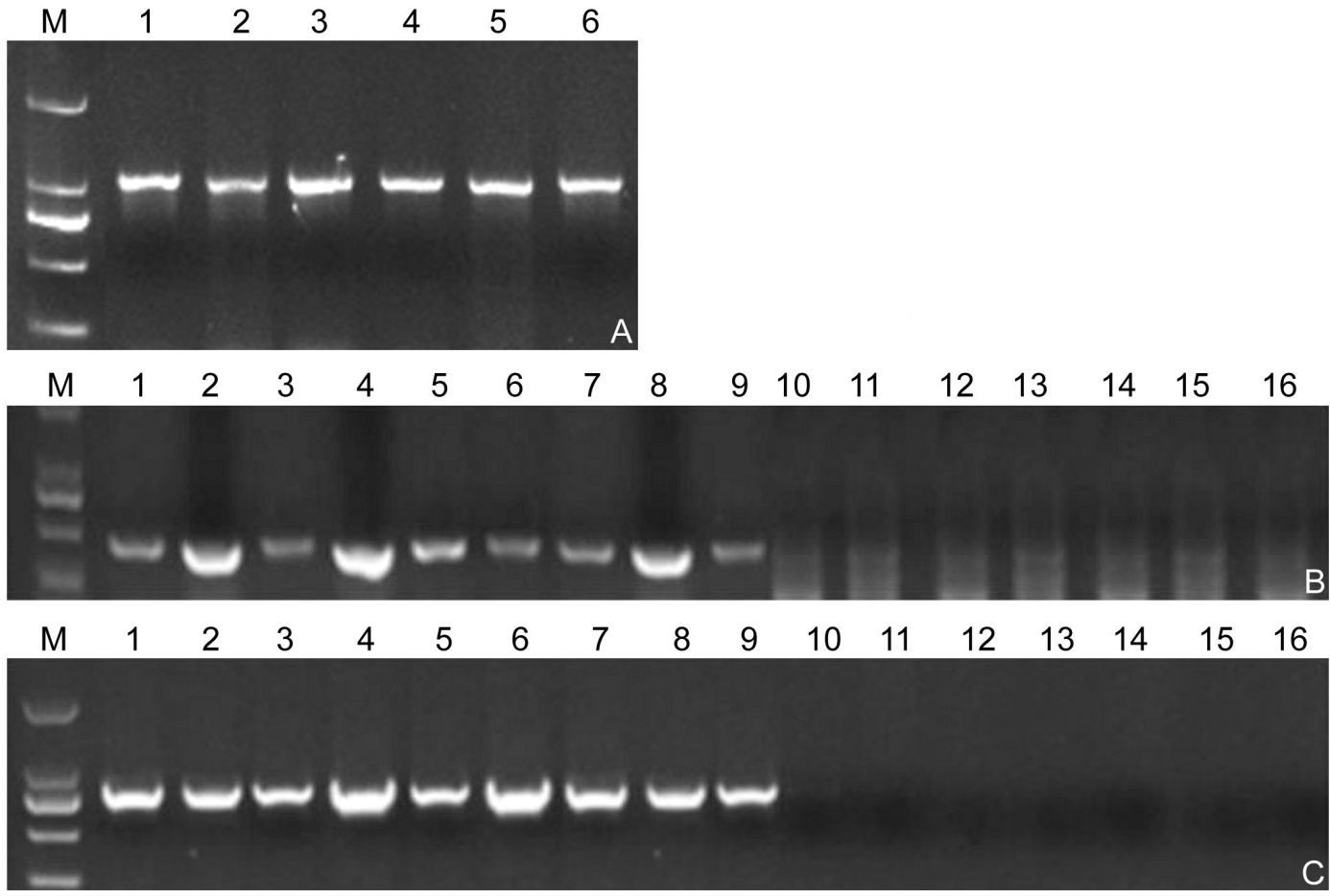

Fig. 3. Detection of transformed tomato plants by PCR. M - DL2000, 1 to 6 - products obtained using primers $p 35 S P$ and $T Y-R(A)$. Detection of TYLCV and ToCV using primers shanghaiF/R $(B)$ and ToCV CP-F/R $(C)$; M - DL2000, 1 - untransformed control plants, 2 to 9 - transgenic plants Nos 4, 9, 10,11,13, 6, 7, and 15; 10 to 16 - transgenic plants Nos 1, 2, 3, 5, 8, 12, and 14 . 
and the transgenic plants showed resistance to TMV (Yan et al. 2007). The CP of the Cucumber green mottle mosaic virus (CGMMV) was transformed into Nicotiana benthamiana, and the transgenic plants became resistant to CGMMV (Kamachi et al. 2007). Agrobacterium-mediated tomato transformation and regeneration of transgenic lines expressing the tomato leaf curl virus (TLCV) CP gene resulted in resistance against TLCV infection (Raj et al. 2005). There are also some reports where the $C P$ genes of two or three viruses were fused to construct an expression vector and carry out genetic transformation. For example, a binary RNAi expression vector was constructed with the conserved sequence of the $C P$ gene of Grapevine leaf roll virus (GLRaV) and Grapevine fan leaf virus (GFLV) using Gateway technology (Tian and Niu 2012). In addition, a Lily symptomless virus and Lily mottle virus binary plant RNAi vector was also constructed using Gateway technology (Xu et al., 2011). These studies have provided a good foundation for the control of plant viruses using the $C P$ gene. Co-infection by TYLCV and ToCV is common in the field, and thus the construction of a vector against only a single virus is insufficient. In this study, the $C P$ genes of TYLCV and ToCV were ligated together, and the RNAi binary expression vector was successfully constructed and transformed into a tomato.

We found that when the 15 transgenic plants were challenged by ToCV and TYLCV, the resistance of the plants to ToCV and TYLCV differed. This may be due to the number of copies of exogenous genes in the genome and the insert position. It is thus also necessary to detect the copy number and integration sites on the transgenicpositive plants.

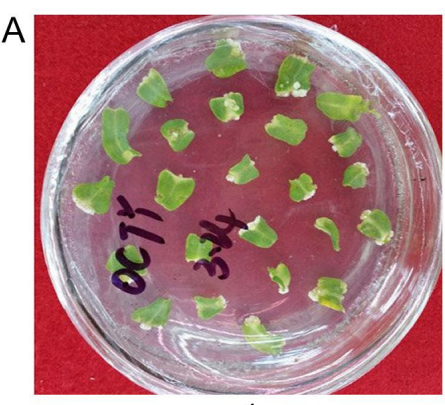

1

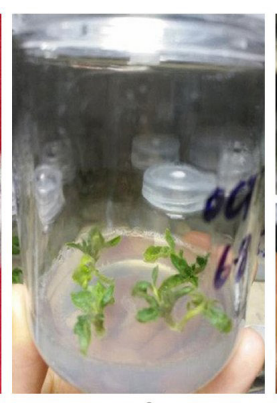

2

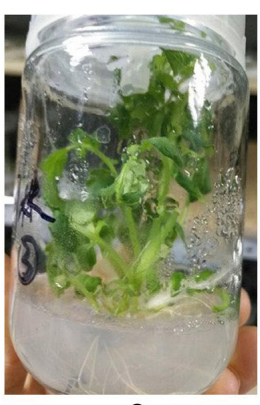

3

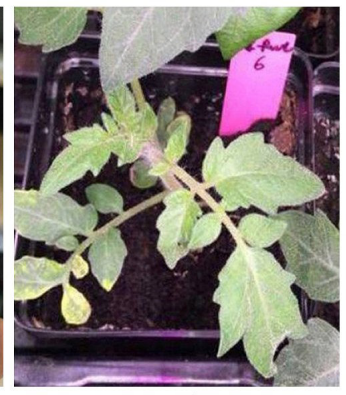

4

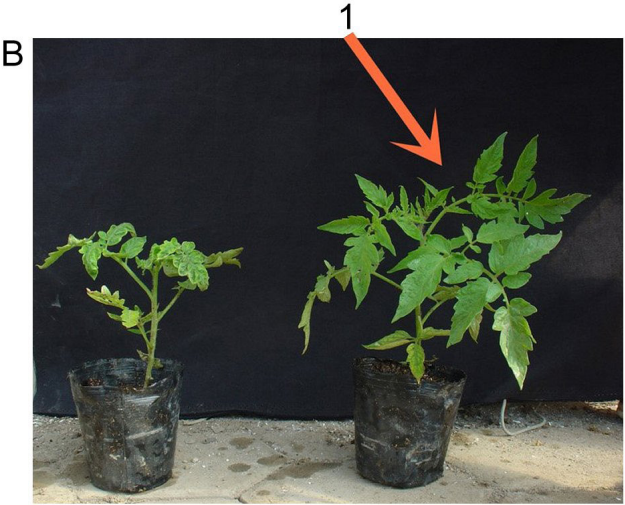

CK

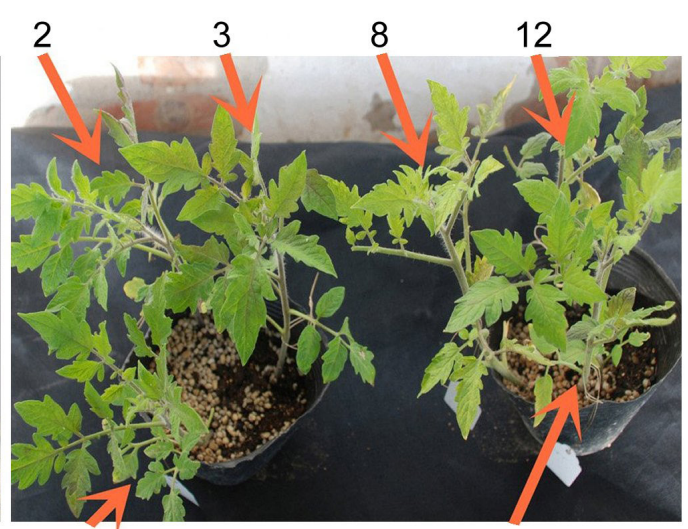

5

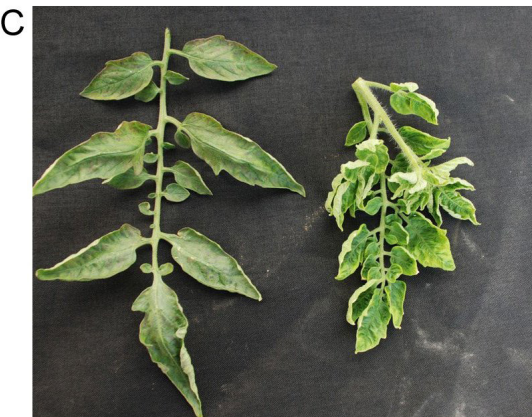

1

2

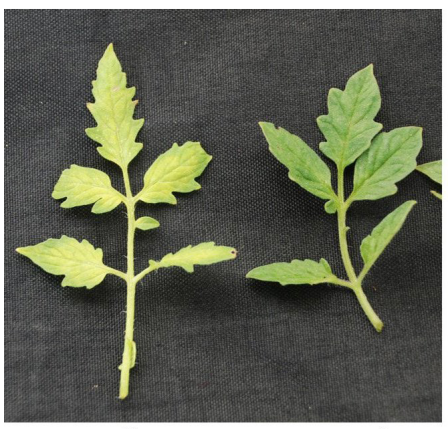

3

Fig. 4. A - Tomato transformed by Agrobacterium; 1 - transformed cotyledons, 2 - induction of buds; 3 - induction of roots, 4 - regenerated plants; $B$ - untransformed control plant (CK), transgenic plants Nos 1, 2, 3, 5, 8, 12, and 14; $C$ - new leaves of transgenic plant No. 1 (1), new leaves of untransformed control plants (2), old leaves of untransformed control plants (3), old leaves of transgenic plant No. 1 (4). 
Our results provide a preliminary approach for achieving resistance against ToCV and TYLCV infection in transgenic tomato plants. The method developed for tomato transformation has a wide scope for the generation of transgenic plants using other genes of interest.

\section{References}

Baulcombe, D.: Viruses and gene silencing in plants. - Arch. Virol. 15 (Suppl.): 189-201, 1999.

Chinnaraja, C., Ramkissoon, A., Ramsubhag, A., Jayaraj, J.: First report of Tomato yellow leaf curl virus infecting tomatoes in Trinidad. - Plant Dis. 100: 1958, 2016.

Exposito-Rodriguez, M., Laissue, P.P., Lopez-Calcagno, P.E., Mullineaux, P.M., Raines, C.A., Simkin, A.J.: Development of pGEMINI, a plant Gateway destination vector allowing the simultaneous integration of two cDNA via a single LRclonase reaction. - Plants 6: 55, 2017.

Hartley, J.L., Temple, G.F., Brasch, M.A.: DNA cloning using invitrosite 2 specific recombination. - Genome Res. 10:17881795, 2000.

Jin, F.M., Xue, J., Jia, Y. H., Zhou, X. M., Wang, J. J., Liu, Z.Q.: Cloning and sequence analysis of TYLCV DNA-A in Tianjin. - Acta agr. boreali-sin. 26: 58-62, 2011.

Jin, F.M., Xue, J., Song, J., Yu, H.T., Duan,H.Y. :Molecular detection and partial genome sequence analysis of tomato chlorosis virus in Tianjin. - Acta agr. boreali-sin. 31: 23-27, 2016.

Kamachi, S., Mochizuki, A., Nishiguchi, M., Tabei, Y.: Transgenic Nicotiana benthamiana plants resistant to cucumber green mottle mosaic virus based on RNA silencing. - Plant Cell Rep. 26: 1283-1288, 2007.

Karimi, M., Inzé, D., Depicker, N.: GATEWAY vectors for Agrobacterium-mediated plant transformation. - Trends Plant Sci. 7: 193-195, 2002.

Kunik, T., Salomon, R., Zamir, D., Navot, N., Zeidan, M., Michelson, I., Gafni, Y., Czosnek H.: Transgenic tomato plants expressing the tomato yellow leaf curl virus capsid protein are resistant to the virus. - Bio/Technology 12: 500504, 1994

Liu, W., Shi, X.B., Tang, X., Zhang, Y., Zhang, D.Y., Zhou, X.G., Liu, Y.: Molecular identification of Tomato chlorosis virus and Tomato yellow leaf curl virus in Yunnan province. - Acta hort. sin. 45: 552-560, 2018.

McCormick, S.: Transformation of tomato with Agrobacterium tumefaciens. - Plant Tissue Cult. Manage. 6: 1-9, 1991.

McCormick, S., Niedermeyer, J., Fry, J., Barnason, A., Horsch, R., Fraley, R.: Leaf disc transformation of cultivated tomato (Lycopersicon esculetum) using Agrobacterium tumefaciens. - Plant Cell Rep. 5: 81-84, 1986.

Niu, Y.B.: Tobacco Antiviral Genetic Engineering Research. Zhejiang University, Hangzhou 2003.

Oey, M., Ross, I.L., Hankamer, B.: Gateway-assisted vector construction to facilitate expression of foreign proteins in the chloroplast of single celled algae. - Plos ONE 9: e86841, 2014.

Pasev, G., Radeva, V., Kostova, D.: First report of tomato infectious chlorosis virus on tomato in Bulgaria. - J. Phytopathol. 160: 160-162, 2012.

Pilowsky, M., Cohen, S.: Tolerance to tomato yellow leaf curl virus derived from Lycopersicon peruvianum. - Plant Dis. 74:
248-250, 1990.

Raj, S.K., Singh, R., Pandey, S.K., Singh, B.P.: Agrobacteriummediated tomato transformation and regeneration of transgenic lines expressing Tomato leaf curl virus coat protein gene for resistance against TLCV infection. - Curr. Sci. 88: 1674-1679, 2005.

Salim, L., Feger, C., Busso, D.: Construction of a compatible Gateway-based co-expression vector set for expressing multiprotein complexes in E. coli. - Anal. Biochem. 512: 110113, 2016

Song, J., Xue, J., Jin, F.M., Sun, H.B., Zhang, Y., Wang, S., Fan, H., Zhou, X.M., Chen, R.: Partial virus gene sequence and real-time quantitative PCR analysis of tomato after mixed infection of ToCV and TYLCV. - Acta agr. boreali-sin. 34: 95-102, 2019.

Stoutjesdijk, P.A., Singh, S.P., Liu, Q., Hurlstone, C.J., Waterhouse, P.M., Green, A.G.: hpRNA-mediated targeting of the Arabidopsis FAD2 gene gives highly efficient and stable silencing. - Plant Physiol. 129: 1723-1731, 2002.

Tian, L.L., Niu, L.: Construction of virus resistant RNAi expression vector of Malus and genetic transformation to tobacco. - Mol. Plant Breed. 11: 783-789, 2013.

Tian, L.L., Niu, L .:Construction of binary RNAi expression vector with virus resistance and genetic transformation in tobacco. - J. Fruit Sci. 29: 997-1003, 2012.

Wang, G.L., Fang, H.J.: Plant Genetic Engineering. Version 2. Science Press, Beijing 2002.

Wang, M.B., Abbott, D.C., Waterhouse, P.M.: A single copy of a virus-derived transgene encoding hairpin RNA gives immunity to barley yellow dwarf virus. - Mol. Plant Pathol. 1: 347-356, 2000

Waterhouse, P.M., Graham, M.V., Wang, M.B.: Virus resistance and gene silencing in plants can be induced by simultaneous expression of sense and antisense RNA. - Proc. nat. Acad. Sci. USA. 95: 13959-13964, 1998.

Wisler, G.C., Duffus, J.E., Liu, H.Y., Li, R.H.: Ecology and epidemiology of white-transmitted closteroviruses. - Plant Dis. 82: 270-280, 1998

Wu, S.H., Li, T.F., Zhao, W.H., Cheng, Z.B., Guo, Q.Y., Zhao, T.M., Yu, W.G., Zhu, Y.Q., Ji, Y.H.: Molecular identification on mixed infection of Tomato yellow leaf curl virus and Tomato chlorosis virus on tomato in Jiangsu Province. - Acta hort. sin. 43: 89-99, 2016.

Xu, P.S., Bai, J.F., Liu, J.W., Li, H.G.: Construction of LSV and LMoV binary virus resistant RNAi vector using Gateway technology. - Chinese agr. Sci. Bull. 27: 144-147, 2011.

Yan, P.Q., Bai, X.Q., Wan, X.Q., Guo, Z.K., Li, L.J., Gong, H.Y., Chu, C.C.: Expression of TMV coat protein gene RNAi in transgenic tobacco plants confer immunity to tobacco mosaic virus infection. - Hereditas 29: 1018-1022, 2007.

Zakay, Y., Navot, N., Zeidan, M., Kedar, N., Rabinowitch, H.D., Czosnek, H., Zamir, D.: Screening of Lycopersicon accessions for resistance to tomato yellow leaf curl virus: presence of viral DNA and symptom development. - Plant Dis. 75: 279281,1990 .

Zhang, F., Jiang, L.: Virus-resistance of papaya Ringspot virus mediated by double-strand RNA. - Plant Sci. J. 29: 385-391, 2011.

Zhao, L.M., Li, G., Liu, Y.G., Guo, J.J., Wei, J.P., Zhu, X.P.: Molecular identification on mixed infections of Tomato chlorosis virus and Tomato yellow leaf curl virus. - China Vegetables 12: 15-20, 2014. 